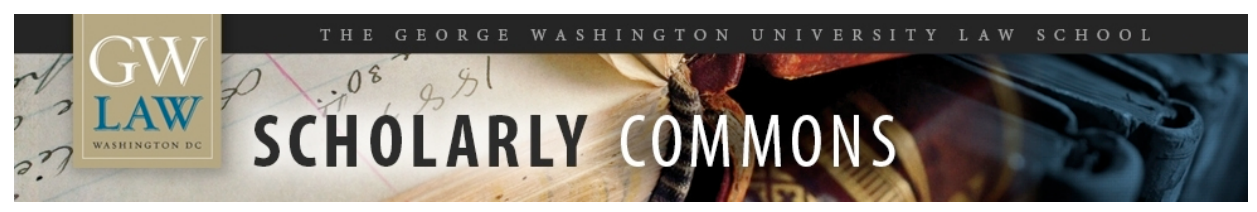

\title{
It's Time to Regulate Stablecoins as Deposits and Require Their Issuers to Be FDIC-Insured Banks
}

Arthur E. Wilmarth Jr.

George Washington University Law School, awilmarth@law.gwu.edu

Follow this and additional works at: https://scholarship.law.gwu.edu/faculty_publications

Part of the Law Commons

\section{Recommended Citation}

41 Banking \& Financial Services Policy Report No. 2 (Feb. 2022), at 1-20.

This Article is brought to you for free and open access by the Faculty Scholarship at Scholarly Commons. It has been accepted for inclusion in GW Law Faculty Publications \& Other Works by an authorized administrator of Scholarly Commons. For more information, please contact spagel@law.gwu.edu. 


\section{It's Time to Regulate Stablecoins as Deposits and Require Their Issuers to Be FDIC-Insured Banks}

Arthur E. Wilmarth, Jr.*

December 16, 2021

\section{Introduction}

In November 2021, the President's Working Group on Financial Markets (PWG) issued a report analyzing the rapid expansion and growing risks of the stablecoin market. As explained in PWG's report, "[s]tablecoins are digital assets that are designed to maintain a stable value relative to a national currency or other reference assets." ${ }^{1}$ PWG's report determined that stablecoins pose a wide range of potential hazards, including the risks of inflicting large losses on investors, destabilizing financial markets and the payments system, supporting money laundering, tax evasion, and other forms of illicit finance, and promoting dangerous concentrations of economic and financial power.

PWG's report called on Congress to pass legislation that would (i) require all issuers of stablecoins to be banks that are insured by the Federal Deposit Insurance Corporation (FDIC), and (ii) "ensure that payment stablecoins are subject to appropriate federal prudential oversight on a consistent and comprehensive basis." PWG also recommended that federal agencies and the Financial Stability Oversight Council (FSOC) should use their "existing authorities" to "address risks associated with payment stablecoin arrangements ... to the extent possible."2

\footnotetext{
*Professor Emeritus of Law, George Washington University Law School.

${ }^{1}$ President's Working Group on Financial Markets et al., Report on Stablecoins (Nov. 2021) (quote at 1) [hereinafter PWG Stablecoin Report], https://home.treasury.gov/system/files/136/StableCoinReport_Nov1_508.pdf; see also Alexis Goldstein, Written Testimony before the Senate Comm. on Banking, Housing, and Urban Affairs 1 (Dec. 14, 2021) ("Stablecoins are crypto assets that attempt to maintain a stable value, either through a basket of reserve assets acting as collateral (asset-backed stablecoins), or through algorithms (algorithmic stablecoins).") [hereinafter Goldstein Testimony], https://www.banking.senate.gov/imo/media/doc/Goldstein\%20Testimony\%201214-21.pdf. This paper focuses on asset-backed stablecoins, which account for most of the stablecoin market. ${ }^{2}$ PWG Stablecoin Report, supra note 1, at 16, 18.
} 
At present, stablecoins are mainly used to make payments for trades in cryptocurrency markets and to provide collateral for derivatives and lending transactions involving cryptocurrencies. ${ }^{3}$ However, technology companies are exploring a much broader range of potential uses for stablecoins, including their use as digital currencies for making purchases and sales of goods and services as well as person-to-person payments. In October, Facebook launched a "pilot" of its Novi "digital currency wallet," which uses the Pax Dollar stablecoin as its first digital currency. ${ }^{4}$ Novi enables its customers to make person-to-person payments within and across national borders and is part of Facebook's larger plan to establish itself as "a challenger in the payments system." Facebook intends to "migrate" Novi's digital wallet to its proposed Diem stablecoin as soon as Facebook receives regulatory approvals for Diem. ${ }^{6}$

Facebook's launch of Novi indicates that stablecoins could potentially become a form of "private money" that is widely used in consumer and commercial transactions. Federal agencies have not yet issued rules governing the issuance and distribution of stablecoins. Federal and state officials have only rarely enforced consumer and investor protection laws against issuers and distributors of stablecoins. PWG's report calls on federal agencies and Congress to take

\footnotetext{
${ }^{3}$ Id. at 7-10; see also Andrew Ackerman, "Stablecoins in Spotlight as U.S. Begins to Lay Ground for Rules on Cryptocurrencies," Wall Street Journal (Sept. 25, 2021) ("For now, stablecoins are used mainly by investors to buy and sell crypto assets on exchanges ... [and] as collateral for derivatives"), https://www.wsj.com/articles/stablecoins-in-spotlight-as-u-s-begins-to-lay-ground-for-rules-on-cryptocurrencies11632562202 ?mod=article inline; Statement by SEC Chair Gary Gensler, "President's Working Group Report on Stablecoins" (Nov. 1, 2021) [hereinafter Gensler Statement], https://www.sec.gov/news/statement/genslerstatement-presidents-working-group-report-stablecoins-110121 (stating that "more than 75 percent of trading on all crypto trading platforms occurred between a stablecoin and some other token" in October 2021).

${ }^{4}$ See infra notes 17-21, 45-47 and accompanying text.

${ }^{5}$ Hannah Murphy \& Siddarth Venkataramakrishnan, "Facebook says ready to launch digital wallet," Financial Times (Aug. 18, 2021) (quoting David Marcus, who was then the leader of Facebook's Novi project), https://www.ft.com/content/a8512417-1fde-481a-b282-2f892e3c3b51; Siddarth Venkataramakrishnan \& Hannah Murphy, "Facebook launches digital wallet Novi," Financial Times (Oct. 19, 2021), https://www.ft.com/content/b9a61950-a32c-4c77-95fe-fc0d00021a0f.

${ }^{6}$ Venkataramakrishnan \& Murphy, supra note 5 (quoting David Marcus).
} 
immediate steps to establish a federal oversight regime that could respond effectively to the dangers created by stablecoins. ${ }^{7}$

This paper strongly supports three regulatory approaches recommended in PWG's report. First, the Securities and Exchange Commission (SEC) should use its available powers to regulate stablecoins as "securities" and protect investors and securities markets. However, the scope of the SEC's authority to regulate stablecoins is not clear, and federal securities laws do not provide adequate safeguards to control the systemic threats that stablecoins pose to financial stability and the payments system.

Second, the Department of Justice (DOJ) should designate stablecoins as "deposits" and should bring enforcement actions to prevent issuers and distributors of stablecoins from unlawfully receiving "deposits" in violation of Section 21(a) of the Glass-Steagall Act. Section 21(a) offers a promising avenue for regulatory action, but its provisions contain uncertainties and gaps and do not provide a complete remedy for the hazards created by stablecoins. The most significant gap in Section 21(a) allows state (and possibly federal) banking authorities to charter special-purpose depository institutions that could issue and distribute stablecoins without obtaining deposit insurance from the FDIC.

Third, Congress should adopt legislation mandating that all issuers and distributors of stablecoins must be FDIC-insured banks. That requirement would compel all stablecoin issuers

\footnotetext{
${ }^{7}$ PWG Stablecoin Report, supra note 1, at 2-3, 10-18. For additional discussions of the dangers created by stablecoins and possible regulatory responses to those perils, see Ackerman, supra note 3; Testimony by Hilary J. Allen before the Senate Comm. on Banking, Housing, and Urban Affairs (Dec. 14, 2021) [hereinafter Allen Testimony], https://www.banking.senate.gov/imo/media/doc/Allen\%20Testimony\%2012-14-211.pdf; Dan Awrey, Bad Money, 106 Cornell Law Review 1, 6-8, 39-45 (2020); Nate DiCamillo, "The US is dragging its heels on critical stablecoin regulations," Quartz (Nov. 8, 2021), https://qz.com/2083636/what-are-stablecoins-and-how-will-they-beregulated/; Gary Gorton \& Jeffrey Y. Zhang, "Taming Wildcat Stablecoins" (Sept. 30, 2021), available at http://ssrn.com/abstract=3888752; Jeanna Smialek, "Why Washington Worries About Stablecoins," New York Times (Sept. 23, 2021), https://www.nytimes.com/2021/09/17/business/economy/federal-reserve-virtual-currencystablecoin.html.
} 
and distributors and their parent companies to comply with federal laws that protect the safety, soundness, and stability of our banking system and obligate banks to operate in a manner consistent with the public interest. Requiring stablecoin issuers and distributors to be FDICinsured banks would also maintain the longstanding U.S. policy of separating banking and commerce. It would prevent Facebook and other Big Tech firms from using stablecoin ventures as building blocks for "shadow banking" empires that would erode consumer protections, impair competition, subvert the effectiveness of financial regulation, and potentially unleash systemic crises across our financial and commercial sectors during severe economic downturns and financial disruptions.

\section{Analysis}

\section{The Rapid Expansion and Escalating Risks of Stablecoins}

The volume of outstanding stablecoins has mushroomed during the past two years, growing from less than $\$ 6$ billion in January 2020 to $\$ 150$ billion in December $2021 .{ }^{8}$ The rapid expansion of the stablecoin market has mirrored the explosive growth of all cryptocurrency markets. The total market capitalization of cryptocurrencies increased almost nine-fold - from $\$ 350$ billion to $\$ 3$ trillion - between September 2020 and November $2021 .{ }^{9}$

At present, stablecoins are mainly used to speculate in cryptocurrencies and other digital assets. Stablecoins are the leading form of payment for trades executed on cryptocurrency exchanges, and stablecoins are used as collateral for derivatives and lending transactions involving digital assets. In addition, stablecoins play "a central role in facilitating trading,

\footnotetext{
${ }^{8}$ The Block, "Stablecoins: Total Stablecoin Supply" (visited on Dec. 15, 2021), https://www.theblockcrypto.com/data/decentralized-finance/stablecoins.

${ }^{9}$ Office of Financial Research, Annual Report to Congress 2021, at 49 [hereinafter OFR 2021 Annual Report], https://www.financialresearch.gov/annual-reports/files/OFR-Annual-Report-2021.pdf; Yvonne Lau,

"Cryptocurrencies hit market cap of $\$ 3$ trillion for the first time as Bitcoin and Ether reach record highs," Fortune (Nov. 9, 2021), https://fortune.com/2021/11/09/cryptocurrency-market-cap-3-trillion-bitcion-ether-shiba-inu/.
} 
lending, and borrowing activity" in decentralized finance (DeFi) transactions. DeFi transactions are completed by using smart contracts and "autonomous" distributed ledgers instead of organized exchanges. ${ }^{10}$

Stablecoins enable participants to trade in cryptocurrencies and engage in other digital asset transactions while avoiding the use of fiat currencies and traditional financial institutions. Stablecoins offer a much higher degree of anonymity in conducting such transactions, and many participants use stablecoins to avoid complying with "Know Your Customer" (KYC) requirements, anti-money laundering (AML) laws, tax laws, and sanctions against terrorist financing. ${ }^{11}$ "[V]irtually no KYC/AML checks" are conducted for DeFi transactions, and criminals can "launder proceeds of crime" by exchanging other assets for stablecoins (or vice versa) while "hiding the blockchain money trail."12

Tether, the largest issuer of stablecoins, has issued over $\$ 80$ billion of stablecoins and controls a majority of the stablecoin market. ${ }^{13}$ Tether and the issuers of most other leading stablecoins represent to the public that they hold sufficient "reserves" to maintain a 1-for-1 parity

\footnotetext{
${ }^{10}$ PWG Report, supra note 1, at 5-10 (quote at 9); see also Allen Testimony, supra note 7, at 2-3, 6-14; Goldstein Testimony, supra note 1, at 1-5, 10-13; Gary Silverman, "Cryptocurrency: rise of decentralized finance sparks 'dirty money' fears," Financial Times (Sept. 15, 2021), https://www.ft.com/content/beeb2f8c-99ec-494b-aa76a7be0bf9dae6.

${ }^{11}$ PWG Report, supra note 1, at 1-2, 10-11, 19-21; Gensler Statement, supra note 3; Goldstein Testimony, supra note 1, at 1-2, 5, 13-15; Smialek, supra note 7; see also Zeke Faux, “Anyone Seen Tether's Billions?”, Bloomberg BusinessWeek (Oct. 7, 2021) ("Tether Holdings checks the identity of people who buy coins directly from the company, but once the currency is out in the world, it can be transferred anonymously, just by sending a code. A drug lord can hold millions of Tethers in a digital wallet and send it to a terrorist without anyone knowing."), https://www.bloomberg.com/news/features/2021-10-07/crypto-mystery-where-s-the-69-billion-backing-thestablecoin-tether?sref=f7rH2jWS; JP Koning, "What Happens If All Stablecoin Users Have to Be Identified?", CoinDesk (Sept. 14, 2021) ("Right now, a large chunk of stablecoin usage is pseudonymous. That is, you or I can hold $\$ 20,000$ worth of tether or USD coin stablecoins in an unhosted wallet (i.e., not on an exchange), without having to provide our identities to either Tether or Circle."), https://www.coindesk.com/policy/2021/02/18/whathappens-if-all-stablecoin-users-have-to-be-identified/; Silverman, supra note 10 (reporting on the belief of some cryptocurrency entrepreneurs that "DeFi innovations ... will enable them to break free of [KYC] obligations"). ${ }^{12}$ Goldstein Testimony, supra note 1, at 5, 14 (including quotes from a report, dated Oct. 18, 2021, by Elliptic, a cryptocurrency compliance firm); see also Silverman, supra note 10 (reporting that DeFi "allows a wave of innovation by people trying to launder money through the system") (quoting David Jevans, CEO of CipherTrace, a cryptocurrency intelligence company).

${ }^{13}$ The Block, supra note 8 .
} 
between their stablecoins and the U.S. dollar. However, there are substantial doubts about the adequacy of reserves held by Tether and other issuers. Tether and its affiliates paid more than $\$ 60$ million to settle charges filed by the Office of the New York Attorney General and the Commodity Futures Trading Commission, alleging that Tether's representations about its reserves were false and materially misleading. ${ }^{14}$ In 2021, Tether disclosed that a majority of its reserves consisted of commercial paper and other corporate obligations (reportedly including debts of Chinese companies). At best, the reserves of Tether and other leading stablecoin issuers resemble the assets held by prime money market funds, which experienced systemic investor runs and were forced to accept bailouts from the federal government in 2008 and $2020{ }^{15}$

As discussed in PWG's report, some technology companies have "the stated ambition" to create stablecoin programs that can be "used widely by retail users to pay for goods and services, by corporations in the context of supply chain payments, and in the context of international remittances."16 Facebook's launch of Novi in October 2021 is a "pilot" for Facebook's planned creation of a global digital payments network that will ultimately use Facebook's proposed Diem stablecoin. Novi is available initially to customers in the U.S. and Guatemala, and its first digital currency is the stablecoin USDP (Pax Dollar), issued by Paxos. ${ }^{17}$

\footnotetext{
${ }^{14}$ Commodity Futures Trading Commission, Press Release No. 8450-21, "CFTC Orders Tether and Bitfinex to Pay Fines Totaling \$42.5 Million” (Oct. 15, 2021), https://www.cftc.gov/PressRoom/PressReleases/8450-21; Office of the N.Y. Attorney General, Press Release, "Attorney General James Ends Virtual Currency Trading Platform Bitfinex's Illegal Activities in New York" (Feb. 23, 2021) (imposing an $\$ 18.5$ million fine on Tether and its affiliates), https://ag.ny.gov/press-release/2021/attorney-general-james-ends-virtual-currency-trading-platformbitfinexs-illegal.

${ }^{15}$ Faux, supra note 11; Goldstein Testimony, supra note 1, at 2-5; OFR 2021 Annual Report, supra note 9, at 51-52; Gorton \& Zhang, supra note 7, at 6-16, 21-24; Bill Nelson \& Paige Pidano Paridon, "Stablecoins are backed by 'reserves'? Give us a break," American Banker (Dec. 10, 2021), available at 2021 WLNR 40403852; Arthur E. Wilmarth, Jr., "The Pandemic Crisis Shows That the World Remains Trapped in a 'Global Doom Loop' of Financial Instability, Rising Debt Levels, and Escalating Bailouts," 40 Banking \& Financial Services Policy Report No. 8 (Aug. 2020), at 1, 9-10, available at https://ssrn.com/abstract=3901967 [hereinafter Wilmarth, "Pandemic Crisis"]; Yueqi Yang, "Tether Fails to Dispel Mystery on Stablecoin's Crucial Reserves," Bloomberg Law (Dec. 3, 2021).

${ }^{16}$ PWG Report, supra note 1, at 8.

${ }^{17}$ Venkataramakrishnan \& Murphy, supra note 5; see also Novi Financial, Inc., "Meet Novi," https://www.novi.com/.
} 
According to Facebook, "Novi is a digital wallet that helps you send and receive money instantly and securely." Novi's customers can send and receive payments by using "digital currencies, starting with USDP (Pax Dollar). When you add money to your Novi account, we'll convert it to USDP. On Novi, 1 USDP is equal to 1 US dollar."18 Novi's terms of service allow customers to redeem their stablecoins from Novi based on the same 1-for-1 parity between the Pax Dollar and the U.S. dollar. ${ }^{19}$

Facebook's launch of Novi indicates that stablecoins could potentially expand from their current roles in cryptocurrency trading and other digital asset transactions to a much broader range of uses in consumer and commercial transactions. On October 19, 2021, David Marcus, who was then head of Novi, described Facebook's ambitions to create a general-use digital payments network:

Beyond the pilot, our business model is clear. We're a challenger in payments. We'll offer free person-to-person payments using Novi. Once we have a solid customer base, we'll offer cheaper merchant payments and make a profit on merchant services. ${ }^{20}$

Marcus explained that “our support for Diem hasn't changed and we intend to launch Novi with Diem once it receives regulatory approval." Marcus also confirmed that Novi planned to offer "interoperability" in payments between Facebook's Diem, Pax Dollar, and other stablecoins. ${ }^{21}$

\footnotetext{
${ }^{18}$ Novi Financial, Inc., "Novi: How It Works,” https://www.novi.com/how-it-works.

${ }^{19}$ Novi Financial, Inc., "Terms of Service (Last Modified: October 19, 2021)" [hereinafter Novi Terms of Service], II 3 ("User Redemption Right") ("You are entitled to redeem each Digital Currency for one U.S. dollar (USD) with Novi."), https://www.novi.com/legal/app/us/terms-of-service?temp_locale=en_US

${ }^{20}$ Tweet by David Marcus (Oct. 19, 2021), https://twitter.com/davidmarcus/status/14504474443379013122 (visited on Dec. 15, 2021).

${ }^{21}$ Id.; see also Venkataramakrishnan \& Murphy, supra note 5 (reporting on Marcus' statements about Facebook's ambitions for Novi).
} 
As discussed in PWG's report, stablecoins present a wide array of potential hazards, including deceptive marketing, fraudulent and manipulative trading, abusive and predatory terms, and facilitating evasion of KYC/AML requirements, tax laws, and sanctions against terrorist financing. ${ }^{22}$ This paper focuses on four systemic dangers posed by stablecoins, which are also analyzed in PWG's report. First, investors in stablecoins could suffer large losses from investor runs triggered by concerns about the adequacy of stablecoin reserves. Investor runs on stablecoins would likely resemble the investor runs that occurred in 2008 and 2020 in prime money market funds, which invest (like stablecoins) in securities that are not issued or guaranteed by the federal government. Stablecoins are also similar to the private banknotes that state-chartered banks issued before the Civil War. Many state-chartered banks experienced runs by holders of their banknotes during that period because they did not hold adequate reserves and their notes were not guaranteed by the federal government. ${ }^{23}$

Second, the collapse of a major stablecoin could destabilize financial markets. For example, a default by Tether - the leading form of payment used in cryptocurrency transactions - would probably cause widespread trading failures as well as fire sales in cryptocurrency markets. If stablecoins became a widely-accepted medium of payment for purchases and sales of goods and services in the general economy, the failure of a leading stablecoin could trigger a

\footnotetext{
${ }^{22}$ PWG Stablecoin Report, supra note 1, at 1-2, 10-11, 19-21; Goldstein Testimony, supra note 1, at 5-15; see also Letter from Open Markets Institute to federal regulatory agencies, dated Nov. 23, 2021, expressing concerns about "Facebook's Digital Asset Wallet Pilot" [hereinafter Open Markets Facebook Letter], at 1-7, https://www.openmarketsinstitute.org/publications/letter-to-regulators-grave-risks-of-facebook-digital-wallet-pilot. ${ }^{23}$ PWG Stablecoin Report, supra note 1, at 1-2, 10-12; see also Ackerman, supra note 3; Awrey, supra note 7, at 36, 11-18, 33-39; Gorton \& Zhang, supra note 7, at 21-31; James Mackintosh, "Bitcoin's Reliance on Stablecoins Harks Back to the Wild West of Finance," Wall Street Journal (May 27, 2021), https://www.wsj.com/articles/bitcoins-reliance-on-stablecoins-harks-back-to-the-wild-west-of-finance11622115246.; Arthur J. Rolnick \& Warren E. Weber, "Free Banking, Wildcat Banking, and Shinplasters," 6 Quarterly Review No. 3, at 10-19 (Fed. Res. Bank of Minneapolis, Fall 1982).
} 
generalized run on stablecoins that might shut down the payments system and inflict widespread losses on consumers, business firms, and financial institutions. ${ }^{24}$

Third, issuers and distributors of stablecoins are rapidly becoming a new category of systemically important "shadow banks." Shadow banks provide functional substitutes for deposits ("shadow deposits") and offer other financial services that mimic the activities of banks while avoiding compliance with federal laws that establish essential safeguards for the safety, soundness, and stability of our banking system. The systemic significance of stablecoin issuers would increase exponentially if stablecoins are widely accepted as a medium of payment in consumer and commercial transactions. Under those circumstances, stablecoins would likely become a systemically important form of "private money" comparable to money market funds, which do not have explicit government backing but rely on general expectations of government support during severe economic downturns or financial crises. ${ }^{25}$

Fourth, issuers and distributors of stablecoins are permitted to combine their financial activities with commercial ventures because they are not defined as "banks" for purposes of the Bank Holding Company Act (BHC Act). Like other shadow banks, issuers and distributors of stablecoins are not subject to the BHC Act's longstanding policy of separating banking and commerce. $^{26}$ As the PWG's report correctly pointed out,

\footnotetext{
${ }^{24}$ PWG Stablecoin Report, supra note 1, at 1-3, 12-14; see also OFR 2021 Annual Report, supra note 9, at 49-54; Sam Knight, "Biden Administration Is Playing With Fire by Failing to Regulate Cryptocurrency," Truthout (Nov. 16, 2021), https://truthout.org/articles/biden-administration-is-playing-with-fire-by-failing-to-regulatecryptocurrency/.

${ }_{25}^{25}$ PW Stablecoin Report, supra note 1, at 1-3, 7-14; see also Gorton \& Zhang, supra note 7, at 3-6, 21-24, 33, 38; Wilmarth, "Pandemic Crisis," supra note 15, at 6-13, 16-17; Arthur E. Wilmarth, Jr., Taming the Megabanks: Why We Need a New Glass-Steagall Act 150-57, 279-88, 341-44, 353-56 (Oxford Univ. Press, 2020) [hereinafter Wilmarth, Taming the Megabanks].

${ }^{26} 12$ U.S.C. $\S \S 1841$ (c), 1843; Arthur E. Wilmarth, Jr., "The OCC's and FDIC's Attempts to Confer Banking Privileges on Nonbanks and Commercial Firms Violate Federal Laws and Are Contrary to Public Policy," 39 Banking \& Financial Services Policy Report No. 10 (Oct. 2020), at 1, 6-11, available at https://ssrn.com/abstract=3750964 [hereinafter Wilmarth, "Banking Privileges"]; see also Gorton \& Zhang, supra note 7 , at $17-19$.
} 
[T]he combination of a stablecoin issuer or wallet provider and a commercial firm could lead to an excessive concentration of economic power. These policy concerns are analogous to those traditionally associated with the mixing of banking and commerce, such as advantages in accessing credit or using data to market or restrict access to products. This combination could have detrimental effects on competition and lead to market concentration in sectors of the real economy. ${ }^{27}$

As explained below in Part 2(c), permitting issuers and distributors of stablecoins to operate without being chartered and regulated as FDIC-insured banks would enable Facebook and other Big Tech firms to enter the banking business and undermine the BHC Act's policy of separating banks from commercial enterprises. Allowing Big Tech firms to subvert that policy would inflict great harm on our financial system, economy, and society.

\section{Regulatory Strategies for Controlling the Dangers of Stablecoins}

This section strongly endorses three regulatory approaches discussed in PWG's report for addressing the perils created by stablecoins. First, the SEC should use its existing powers to regulate stablecoins as "securities" and protect investors and securities markets. Second, DOJ should designate stablecoins as "deposits" and bring enforcement actions to prevent issuers and distributors of stablecoins from violating Section 21(a) of the Glass-Steagall Act. Third, to overcome uncertainties and gaps that limit the effectiveness of SEC and DOJ remedies, Congress should pass legislation requiring all issuers and distributors of stablecoins to be FDIC-insured banks. ${ }^{28}$

${ }^{27}$ PWG Stablecoin Report, supra note 1, at 14.

${ }^{28} I d$. at $2-3,15-18$. 


\section{a. The SEC should use its existing powers to regulate stablecoins as "securities."}

The SEC should exercise its existing authority to regulate stablecoins as "securities," thereby requiring issuers and distributors of stablecoins to comply with federal securities laws that protect investors and securities markets by (1) prohibiting fraud and manipulation in purchases and sales of securities and (2) imposing registration and disclosure duties on those who sell securities to the public. As discussed below, the SEC would face difficult legal challenges in regulating stablecoins as "securities." In addition, the SEC does not possess the broad prudential oversight powers that federal bank regulators can wield to address systemic risks and promote financial stability. Consequently, vigorous efforts by the SEC to regulate stablecoins as "securities" would be a very helpful step, but it would not provide an adequate remedy for the systemic perils created by stablecoins.

The SEC would confront potentially significant obstacles in showing that stablecoins are "securities," especially with regard to stablecoins that do not pay interest and are used solely for the purpose of buying and selling goods and services for consumption. To establish legal grounds for regulating stablecoins as "securities," the SEC must show that stablecoins are “investment contracts" or "notes" (debt obligations) as defined in federal securities laws. ${ }^{29}$ Under the Supreme Court's Howey decision, an "investment contract" is a "scheme [that] involves an investment of money in a common enterprise with profits to come solely from the efforts of others." 30 In SEC v. Edwards, the Supreme Court explained that the "profits" referred to in Howey are "the profits that investors seek on their investment . . . in the sense of income or

\footnotetext{
${ }^{29}$ See 15 U.S.C. $\S \S 77 b(a)(1), 78 c(a)(10), 80 \mathrm{a}-2(\mathrm{a})(36)$; Todd Phillips, The SEC's Regulatory Role in the Digital Assets Markets 5-7 (Center for American Progress, Oct. 2020), available at http://ssrn.com/abstract=3964632.

${ }^{30}$ SEC v. W.J. Howey \& Co., 328 U.S. 293, 301 (1946); see also Phillips, supra note 29, at 5-6.
} 
return, to include, for example, dividends, other periodic payments, or the increased value of the investment." The Court also held in Edwards that "fixed returns" on "investments pitched as low-risk" would satisfy the Howey test, and the ability of investors to redeem their investments would not affect that outcome. ${ }^{31}$

In Reves v. Ernst \& Young, the Supreme Court held that every promissory "note" is presumptively a "security." However, that presumption can be rebutted based on several factors, including whether "the buyer is interested primarily in the profit the note is expected to generate," or, in contrast, whether "the note is exchanged to facilitate the purchase and sale of a minor asset or consumer good." Reves held that courts should also consider (1) whether the note is an instrument in which there is "common trading for speculation or investment," and (2) whether "the existence of another regulatory scheme significantly reduces the risk of the instrument, thereby rendering application of the Securities Acts unnecessary." 32

Federal district courts concluded in several cases that cryptocurrencies created by sellers with fluctuating values were "investment contracts" and "securities" under federal securities laws. In those cases, the sellers represented that their cryptocurrencies could increase in value and provide investment gains to the buyers. ${ }^{33}$ None of those cases involved stablecoins having a fixed value with reference to widely-used fiat currencies or other ostensibly "safe" assets, and there do not appear to be any reported court decisions addressing the issue of whether such stablecoins are "securities."

\footnotetext{
${ }^{31}$ SEC v. Edwards, 540 U.S. 389, 394-97 (2004).

${ }^{32}$ Reves v. Ernst \& Young, 494 U.S. 56, 64-67 (1990); see also Phillips, supra note 29, at 6.

${ }^{33}$ See, e.g., SEC v. NAC Foundation, LLC, 512 F. Supp. 2d 988, 994-97 (N.D. Cal. 2021); SEC v. Kik Interactive Inc., 492 F. Supp. 2d 169, 177-80 (S.D.N.Y. 2020); SEC v. Telegram Group Inc., 448 F. Supp. 2d 352, 364-79 (S.D.N.Y. 2020); Balestra v. ATBCoin LLC, 380 F. Supp. 2d 340, $352-57$ (S.D.N.Y. 2019); SEC v. Shavers, No. 4:13-CV-416, 2014 WL 12622292, at*4-*8 (E.D. Tex. Aug. 26, 2014).
} 
Issuers of the most widely-used stablecoins (including Tether, USD Coin, and Pax Dollar) represent that their stablecoins will maintain a 1-to-1 parity with the U.S. dollar by holding reserves that include cash, government securities, and (in most cases) corporate debt obligations. Most leading stablecoins do not pay interest to their holders. Thus, instead of promising potential gains, issuers of most prominent stablecoins assure investors that they will not suffer losses from buying and holding stablecoins. Those stablecoins are different from cryptocurrencies that have fluctuating values and offer buyers the possibility of making profits from trading..$^{34}$

The SEC could argue that stablecoins should be treated as "investment contracts" or "notes" because (1) issuers and distributors offer and sell stablecoins to investors with the shared understanding that stablecoins are the most widely-used form of payment for speculating in cryptocurrencies and other digital assets; ${ }^{35}$ and (2) issuers and distributors expect that most buyers of stablecoins will use their coins to pursue speculative profits by trading in digital assets or by lending their coins to other traders. ${ }^{36}$ Thus, a purchase of stablecoins could reasonably be viewed as the payment of an "entry fee" enabling the buyer to speculate in cryptocurrency markets, just as the purchase of poker chips permits a gambler to participate and place bets in

\footnotetext{
${ }^{34}$ Ackerman, supra note 3; Awrey, supra note 7, at 60 n.221; Nikhilesh De, "SEC Chair Hints Some Stablecoins Are Securities," CoinDesk (Sept. 14, 2021), https://www.coindesk.com/markets/2021/07/21/sec-chair-hints-somestablecoins-are-securities/; DiCamillo, supra note 7; Gorton \& Zhang, supra note 7, at 3, 6-8, 12-16; Smialek, supra note 7; Wilmarth, "Pandemic Crisis," supra note 15, at 9-10.

${ }^{35}$ See supra notes 3 \& 10 and accompanying text.

${ }^{36}$ For court decisions that involved interest-bearing debt instruments but also indicated that financial instruments sold for the purpose of encouraging speculation could be treated as "securities," see, e.g., Gary Plastic Packaging Corp. v. Merrill Lynch, Pierce, Fenner \& Smith, Inc., 756 F.2d 230, 240-42 (2d Cir. 1985) (holding that the defendant broker-dealer sold "investment contracts" that were subject to regulation as "securities" because the defendant sold negotiable bank certificates of deposits (CDs) accompanied by promises that the defendant would monitor the quality of the issuing banks, repurchase the CDs on demand, and maintain a "secondary market" in the CDs, thereby enabling customers to resell their CDs for potential gains without risking any loss of their principal or accrued interest); Stoiber v. SEC, 161 F.3d 745, 747-52 (D.C. Cir. 1998) (holding that the defendant broker sold "notes" that were subject to regulation as "securities" because the defendant sold interest-bearing promissory notes to customers with the understanding that the defendant would use most of the sale proceeds to trade in commodities and generate profits to pay off the notes).
} 
poker games and tournaments. ${ }^{37}$ SEC Chair Gary Gensler recently observed that stablecoins are primarily bought and used for speculative purposes, and he described stablecoins as "acting almost like poker chips at the casino." 38 The SEC could argue that it would be proper to classify stablecoins as "notes" because buyers of stablecoins are "primarily motivated by the opportunity to earn a profit on their money" by using their stablecoins to pay for subsequent speculative transactions. ${ }^{39}$

In contrast, if issuers created stablecoins that could be used only to buy and sell goods and services for consumption, and that could not be used for speculation, it would be much more difficult for the SEC to characterize those stablecoins as "securities." As explained above, court decisions defining "investment contracts" and "notes" have excluded financial instruments that are purchased solely for the purpose of buying and selling goods, other property, or services for consumption, and not for potential investment gains. ${ }^{40}$ Special-purpose, consumption-only stablecoins do not appear to be part of the present digital asset landscape. However, issuers

\footnotetext{
${ }^{37}$ See Tschetschot v. Commissioner, T.C. Memo. 2007-38, 2007 WL 518989, at *3 (U.S.T.C., Feb. 20, 2007) (stating that participants in poker tournaments bought poker chips as part of their "entry fees" for the purpose of "placing bets, hoping to win" prizes).

${ }^{38}$ Gensler Statement, supra note 3; Tory Newmyer, "SEC's Gensler likens stablecoins to 'poker chips' amid calls for tougher crypto regulation," Washington Post (Sept. 21, 2021) (quoting from interview with Mr. Gensler), https://www.washingtonpost.com/business/2021/09/21/sec-gensler-crypto-stablecoins/; see also Opening Statement of Sen. Sherrod Brown at a hearing before the Senate Comm. on Banking, Housing, and Urban Affairs (Dec. 14, 2021) ("Stablecoins make it easier than ever to risk real dollars on cryptocurrencies."), https://www.banking.senate.gov/imo/media/doc/Brown\%20Statement\%2012-14-21.pdf.

${ }^{39}$ Stoiber v. SEC, 161 F.3d at 750.

${ }^{40}$ See, e.g., SEC v. Kik Interactive, 492 F. Supp. 2d at 179-80 (distinguishing between digital assets purchased for a "consumptive use" and those bought primarily for their "profit-making potential"); Solis v. Latium Network, Inc., No. 18-10255 (SDW) (SCM), 2018 WL 6445543, at*1-*3 (D.N.J., Dec. 10, 2018) (holding that digital tokens sold by defendants were "securities" because defendants encouraged plaintiffs to "expect a profit" from investing in the tokens, even though the tokens could also potentially be used to purchase services). For additional analysis of the distinction between financial instruments used solely for consumption and those purchased for investment gains, see SEC "Finhub" Staff, "Framework for 'Investment Contract' Analysis of Digital Assets" (April 3, 2019), Part II.C.3, https://www.sec.gov/corpfin/framework-investment-contract-analysis-digital-assets; Jay B. Sykes, "Securities Regulation and Initial Coin Offerings: A Legal Primer," at 14-19, 26-32 (Congressional Res. Serv. Rep. R45301, Aug. 31, 2018), https://sgp.fas.org/crs/misc/R45301.pdf.
} 
might decide to create such instruments if the SEC succeeded in classifying stablecoins used for speculation as "securities."

The SEC could also seek to regulate issuers of stablecoins as investment companies under the Investment Company Act of 1940 (1940 Act). Issuers of stablecoins that engage primarily in the business of investing and trading in securities, or engage in that business and hold more than $40 \%$ of their assets in non-government securities, could potentially be treated as investment companies. There are numerous exemptions in the 1940 Act that might allow some issuers of stablecoins to avoid being treated as investment companies, and an analysis of those exemptions is beyond the scope of this paper. ${ }^{41}$

The SEC's track record with money market funds - financial instruments that closely resemble stablecoins - does not inspire confidence that the SEC could effectively control the systemic dangers of stablecoins by regulating them as investment companies. The SEC's regulation of money market funds under the 1940 Act failed to ensure the resilience of those funds after Lehman Brothers collapsed in September 2008. Lehman's bankruptcy and default on its commercial paper triggered systemic runs by investors on money market funds, and the Treasury Department and Federal Reserve (Fed) were forced to arrange a comprehensive bailout of those funds. Despite that calamity, the SEC rejected numerous recommendations after 2008 including one from FSOC - calling on money market funds to stop offering fixed net asset values (NAVs) of \$1 per share and to use floating NAVs like other mutual funds. The SEC required institutional prime and tax-exempt money market funds to adopt floating NAVs, and it permitted non-government money market funds to impose restrictions on redemption. However, the SEC allowed retail prime money market funds and institutional and retail government money

\footnotetext{
4115 U.S.C. § 80a-3; see Phillips, supra note 29, at 6-7; SEC, "Investment Company Registration and Regulation
} Package,” https://www.sec.gov/investment/fast-answers/divisionsinvestmentinvcoreg 121504htm.html. 
market funds to continue offering deposit-like treatment with fixed NAVs of \$1 per share.

Money market funds experienced another series of systemic runs by investors in March 2020 and were rescued for a second time by the Treasury and the Fed. ${ }^{42}$

In December 2021, the SEC issued a proposal to amend its money market fund rules to address the problems revealed by the investor runs of 2020. The SEC's proposal would increase liquidity requirements and modify redemption terms for money market funds in order to reduce incentives for investor runs during periods of financial stress. At the same time, the proposal conceded that the SEC's changes to its money market fund rules in 2010 and 2014 did not achieve their intended purpose and failed to prevent the investor runs of $2020 .^{43}$

The SEC's proposal considered - and rejected - the alternative possibility of requiring all money market funds to use floating NAVs. The proposal acknowledged that a new rule requiring floating NAVs for all funds would increase transparency about the risk of money market fund investments.... To the degree that investors in stable NAV funds are currently treating them as if they were holding U.S. dollars due to a lack of transparency about risks of such funds, expanding the scope of the floating NAV requirements may enhance

\footnotetext{
${ }^{42}$ Michael S. Barr, Howell E. Jackson \& Margaret E. Tahyar, Financial Regulation: Law \& Policy 1302-24 (2d ed. 2018); Gorton \& Zhang, supra note 7, at 21-24; Wilmarth, "Pandemic Crisis," supra note 15, at 4-8, 11-12; Wilmarth, Taming the Megabanks, supra note 25, at 153-57, 279-88, 341-44; see also Marco Cypriani \& Gabrielle La Spada, "Sophisticated and Unsophisticated Runs" (Fed. Res. Bank of N.Y. Staff Rep. No. 956, Dec. 2020), https://www.newyorkfed.org/medialibrary/media/research/staff_reports/sr956.pdf; Lei Li, Yi Li, Marco Macchiavelli \& Xing (Alex) Zhou, "Liquidity Restrictions, Runs, and Central Bank Interventions: Evidence from Money Market Funds" (May 24, 2021), available at https://ssrn.com/abstract=3607593.

${ }^{43}$ Securities and Exchange Commission, "Money Market Fund Reforms: Proposed rule" (Dec. 15, 2021) [hereinafter SEC Money Market Fund Proposal], https://www.sec.gov/rules/proposed/2021/ic-34441.pdf. For the SEC's explanation of why its changes to money market fund rules in 2010 and 2014 were inadequate and did not prevent the investor runs of March 2020, see id. at 10-31, 81-97.
} 
investor protections and enable investors to make more informed investment decisions. $^{44}$

The SEC's proposal also recognized that requiring floating NAVs for all funds "would reduce the distortions arising out of implicit government guarantees of money market funds" and likely cause "investors of stable NAV funds to reallocate capital into cash accounts subject to deposit insurance." 45 The resulting shrinkage of the money market fund industry would reduce the demand for short-term wholesale funding instruments, such as securities repurchase agreements (repos) and commercial paper. Money market funds are the most prominent investors in repos and commercial paper. Those short-term debt instruments also function as "shadow deposits" (functional substitutes for bank deposits), and they experienced their own systemic breakdowns in 2008 and 2020. ${ }^{46}$ The SEC's proposal admitted that the support provided by money market funds for short-term wholesale funding markets "may be sustainable, in part, due to perceived government backstops of money market funds and lack of transparency to investors about the risks inherent in money market fund investments." 47

Thus, the SEC's proposal recognized that money market funds with fixed NAVs produce market distortions, depend on implicit government guarantees, and do not provide full transparency to investors. Nevertheless, the SEC's proposal rejected the option of requiring all money market funds to adopt floating NAVs. That rejection suggests that the SEC would be equally unprepared to force stablecoins to abandon their promised 1:1 parity with the U.S. dollar - a promise that conveys to investors the same illusion of deposit-like status.

\footnotetext{
${ }^{44} I d$. at 234.

${ }^{45} I d$. at $236-38$.

${ }^{46}$ Id. at 237-38; see also Wilmarth, "Pandemic Crisis," supra note 15, at 2-8, 12; Wilmarth, Taming the Megabanks, supra note 15, at 153-57, 278-87, 341-44, 353-56.

${ }^{47}$ SEC Money Market Fund Proposal, supra note 43, at 238.
} 
Like money market funds, stablecoins are "shadow deposits" - a type of "private money" that is designed to serve as a functional substitute for federally-insured bank deposits. The bailouts of money market funds in 2008 and 2020 and the close similarities between those funds and stablecoins strongly support the conclusion that both types of financial instruments should be regulated in the same way as bank deposits to control their systemic dangers. ${ }^{48}$ As shown by the vicissitudes of money market funds, regulating stablecoins as investment companies under the 1940 Act would not provide an adequate substitute for requiring stablecoins to comply with the regulatory regime governing FDIC-insured bank deposits.

An additional factor supporting that conclusion is that the SEC lacks broad financial stability powers comparable to the extensive prudential regulatory and supervisory authorities of federal banking agencies. The SEC's core mission is to protect investors and preserve the integrity of securities markets. The SEC generally has not attempted to act as a financial stability regulator. ${ }^{49}$ As shown in the next two sections, regulating stablecoins as deposits and requiring their issuers and distributors to become FDIC-insured banks would provide the most promising approach for controlling their systemic perils.

\section{b. The Department of Justice should enforce Section 21(a) of the Glass- Steagall Act against issuers and distributors of stablecoins.}

Novi provides deposit-like treatment for stablecoins that its customers buy and hold in their accounts. Novi sells stablecoins (currently Pax Dollars) to its customers at a fixed price of $\$ 1$ per coin, and Novi agrees to redeem stablecoins from its customers at the same price of $\$ 1$ per

\footnotetext{
${ }^{48}$ Gorton \& Zhang, supra note 7, at 21-24, 33-35; Wilmarth, "Pandemic Crisis," supra note 15, at 6-10.

${ }^{49}$ See Congressional Research Service, "Who Regulates Whom? An Overview of the U.S. Financial Regulatory Framework" (CRS Report No. R44918, updated Mar. 10, 2020), https://sgp.fas.org/crs/misc/R44918.pdf; Daniel K. Tarullo, "The SEC should - and can - pay more attention to financial stability" (May 13, 2021), https://www.brookings.edu/blog/up-front/2021/05/13/the-sec-should-and-can-pay-more-attention-to-financialstability/; see generally Barr, Tahyar \& Jackson, supra note 42, at 444-502, 535-64.
} 
coin. ${ }^{50}$ Novi's customers own the stablecoins held in their accounts, and Novi agrees to maintain custody of its customer's stablecoins until they are redeemed, withdrawn, or transferred to other persons. ${ }^{51}$ Novi enables its customers to

(i) purchase and hold Digital Currency in your Account, (ii) conduct person-toperson transfers of Digital Currency, (iii) set up recurring Digital Currency transactions, (iv) convert your Digital Currency to local currency and pick up cash; (iv) convert your Digital Currency to local currency and transfer to your linked bank account via an automated clearing house (“ACH”) transaction; and (vi) use any additional features we may provide through your use of the Services. $^{52}$

The services that Novi provides to its customers through their stablecoin accounts satisfy both of the key functional characteristics of "deposits": (1) the placing of funds with another person for custody and safekeeping, and (2) the ability of the depositor to withdraw or transfer those funds on demand or at a definite time. In a 1991 decision, the Second Circuit Court of Appeals held that, "[a]s commonly understood, the term 'deposit' means a sum of money placed in the custody of a bank, to be withdrawn at the will of the depositor."53 Similarly, in a 2016 decision, the Fifth Circuit Court of Appeals explained:

\footnotetext{
${ }^{50}$ Novi Financial, Inc., "How It Works: Add money" ("Simply add a debit card to put money in your account, and it'll be converted to USDP. On Novi, 1 USDP is equal to 1 US dollar."), https://www.novi.com/how-it-works; Novi Terms of Service, supra note 19, If 3 ("User Redemption Right") ("You are entitled to redeem each Digital Currency for one U.S. dollar (USD) with Novi.").

${ }^{51}$ Novi Terms of Service, supra note 19, II 3 ("Title and Ownership") ("Your Account will give you access to buy, sell, transfer, and manage your Digital Currency. The Digital Currency is held by Novi on a blockchain in one or more blockchain addresses (each, a 'Wallet'). . . Novi controls the Wallet that holds your Digital Currency. ... [Y]ou own all beneficial interest in the Digital Currency in your Account."); id. \ 3 ("Custody") ("To more securely custody [sic] Digital Currency, we may use one or more shared, commingled Wallets to hold Digital Currency on your behalf and on our own behalf.").

${ }^{52}$ Novi Terms of Service, supra note 19, II 5 ("Description of the Services").

${ }^{53}$ United States v. Jenkins, 943 F.2d 167, 174 (2d Cir.) (citations omitted), cert. denied, 502 U.S. 1014 (1991).
} 
The relevant authorities demonstrate that the essential elements of a "deposit" include the following. First, a deposit must involve the placement of funds with another for "safekeeping." ... Second, those funds must be subject to the control of the depositor such that they are repayable on demand or at a fixed time. ${ }^{54}$

As shown above, Novi clearly accepts "deposits" by agreeing to (i) receive funds from its customers, (ii) convert those funds into stablecoins at a fixed 1:1 parity with U.S. dollars, (iii) maintain custody of the stablecoins owned by its customers, (iv) repay its customers' funds based on the same fixed parity when its customers decide to redeem their stablecoins, and (v) allow its customers to transfer their stablecoins to other persons. Courts have repeatedly held that nonbanks are deemed to receive "deposits" if they accept funds from other persons while agreeing to hold those funds and repay them on demand or at a specified time. The ability of customers to transfer their funds to third parties is not a prerequisite for status as "deposits," but their right to transfer their funds to third parties provides additional evidence that a deposit relationship has been formed..$^{55}$

Section 21(a) of the Glass-Steagall Act establishes two overlapping prohibitions against the receipt of deposits by nonbanks. Section 21(a)(1) focuses on persons who are engaged in securities activities. Section 21(a)(1) bars issuers, underwriters, distributors, and sellers of

\footnotetext{
${ }^{54}$ MoneyGram Int'l, Inc. v. Commissioner, No. 15-60527, 664 Fed. Appx. 386, 392 (5th Cir., Nov. 15, 2016) (citations omitted); see also MoneyGram Int'l, Inc. v. Commissioner, 999 F.3d 269, 274-76 (5th Cir. 2021). ${ }^{55}$ United States v. Jenkins, 943 F.2d at 174 (holding that the defendant (an individual) accepted a "deposit" when he "took custody" of $\$ 150,000$ on behalf of a purported foreign bank and "agreed to return it at the will" of the depositor, stating "[y]our money will be here for your use"); In re Thaxton Group, Inc., Securities Litigation, C/A No. 8:02-2612-GRA, 2006 WL 8462530, at *1-*3, *9-*14 (D.S.C., Mar. 20, 2006) (holding that the defendant (a nonbank finance company) accepted "deposits" by selling $\$ 121$ million of demand notes to 5,000 investors, thereby "taking money from investors in return for a promise to return the funds on demand," and explaining that the "notes were designed to imitate bank certificates of deposit and money market accounts in order to attract bank depositors to the note program"); $S \&$ N Equipment Co. v. Casa Grande Cotton Finance Co., 97 F.3d 337, 340-45 (9th Cir. 1996) (determining that the defendant (a nonbank finance company) accepted "demand deposits" for purposes of the BHC Act because the defendant "accepted funds from its customers," placed those funds in "credit accounts," and allowed customers to "withdraw funds as needed" and transfer funds to third parties).
} 
"stocks, bonds, debentures, notes, or other securities" from also "engag[ing] at the same time to any extent whatever in the business of receiving deposits subject to check or repayment upon presentation of a passbook, certificate of deposit, or other evidence of debt, or upon request of the depositor." ${ }^{56}$ If Novi's stablecoins are determined to be "securities," Novi would be "engag[ing] at the same time" in both (1) issuing, underwriting, distributing, or selling "securities" and (2) receiving "deposits" that are (A) withdrawn or transferred by customers using functional equivalents of "checks" or (B) repaid to customers upon their request. Section 21(a)(1) clearly forbids that combination of activities. ${ }^{57}$

Court decisions have treated "deposits" as also being "securities" for purposes of the federal securities laws unless those deposits are accepted either by FDIC-insured U.S. banks or by foreign banks subject to a regulatory regime that provides comparable protections to depositors. ${ }^{58}$ Based on those decisions, Novi's stablecoins would be subject to regulation as both "deposits" and "securities" because Novi is not chartered or regulated as a bank and does not have FDIC insurance. Accordingly, DOJ should determine that Novi's stablecoins violate Section 21(a)(1) if those stablecoins are found to be "securities."

Section 21(a)(2) of the Glass-Steagall Act is a broader and more sweeping provision. Section 21(a)(2) prohibits all persons (regardless of whether they are also involved in "securities" activities) from "engag[ing], to any extent whatever ... in the business of receiving deposits" - described with the functional characteristics included in Section 21(a)(1) - unless

\footnotetext{
${ }^{56} 12$ U.S.C. $\$ 378(\mathrm{a})(1)$.

${ }^{57}$ For court decisions applying Section 21(a)(1) and holding that the relevant terms - including "securities," "underwriting," and "dealing" - are generally given the same meaning under federal securities laws and the GlassSteagall Act, see Securities Indus. Ass'n v. Board of Governors, 468 U.S. 137, 148-52 (1984); Investment Co. Institute v. Conover, 790 F.2d 925, 927-28, 933-34 (D.C. Cir.), cert. denied sub nom. Investment Co. Institute v. Clarke, 479 U.S. 939 (1986).

${ }^{58}$ Marine Bank v. Weaver, 455 U.S. 551, 555-59 (1982); SEC v. McDuffie, Civil Action No. 12-cv-02939, 2014 WL 4548723, at *3-*7 (D. Colo., Sept. 15, 2014); SEC v. Stanford Int'l Bank, Ltd., Civil Action No. 3:09-CV-0298-N, 2011 WL 13160374, at*3-*5 (N.D. Tex., Nov. 30, 2011).
} 
those persons satisfy one of three alternative sets of regulatory criteria. Under Section 21(a)(2), a person who engages in the business of receiving deposits must (A) be chartered and authorized to "engage in such business" by, and subject to examination and regulation under, federal laws or the laws of a state, U.S. territory, or the District of Columbia, or (B) be "permitted by" federal laws or the laws of a state, U.S. territory, or the District of Columbia to "engage in such business" and also be subject under the laws of that jurisdiction to "examination and regulation," or (C) submit to "periodic examination by the banking authority" of the state, territory, or District of Columbia where "such business is carried on," and publish "periodic reports of its condition," in "the same manner and under the same conditions" as are required by the laws of such state, territory, or District for chartered banks "engaged in such business in the same locality." ${ }^{, 59}$ It bears repeating that Section 21(a)(2) - unlike Section 21(a)(1) - applies to all persons who engage in the business of receiving deposits, regardless of whether they are also issuing, underwriting, distributing, or selling "securities."

Paragraphs (A) and (B) of Section 21(a)(2) cover much of the same ground - as both paragraphs refer to institutions that are legally authorized to engage in "the business of receiving deposits" - except that paragraph (A) refers to chartering, examination, and regulation while paragraph (B) refers to examination and regulation but not chartering. Paragraph (C) describes persons who are subject to "periodic examination" by a state, District, or territorial "banking authority" and who also submit "periodic reports," with such examination and reports to be made "in the same manner and under the same conditions" as are required for chartered banks engaged in the business of receiving deposits in the same state, District, or territory. The crucial point is that all three paragraphs in Section 21(a)(2) refer to institutions that are either chartered as,

\footnotetext{
${ }^{59} 12$ U.S.C. $§ 378(a)(2)$.
} 
regulated as, or subject to the same examination and reporting requirements as, deposit-taking banks. Persons who do not satisfy the criteria set forth in any of the three paragraphs would violate Section 21(a)(2) if they engage "to any extent whatever . . in the business of receiving deposits. ${ }^{900}$

As explained above, Novi's activities satisfy Section 21(a)'s functional description of engaging in the "business of receiving deposits subject to check or repayment . . . upon request of the depositor." Novi's deposit-taking business violates Section 21(a)(2) - regardless of whether its stablecoins are treated as "securities" - because Novi does not satisfy any of the criteria set forth in paragraphs (A), (B), or (C). Novi is not chartered as a deposit-taking bank under federal or state laws. Novi is not permitted by federal or state laws to engage in the business of receiving deposits while being examined and regulated in connection with that business. Novi also is not complying with the same examination and reporting requirements as are applied by the "banking authority" of the relevant state, District, or territory to chartered, deposit-taking banks.

Section 21(b) imposes criminal sanctions on persons who violate Section 21(a), and DOJ is therefore responsible for enforcing the statute. In October 1979, a New York savings bank sent a letter to DOJ and the SEC alleging that Merrill Lynch was violating Section 21(a) by offering "cash management" money market funds that were unlawful "deposits." DOJ's Criminal Division issued an opinion in December 1979, which rejected the savings bank's allegations based on a highly formalistic analysis. DOJ classified money market funds as equity investments rather than debt claims, and DOJ concluded that only debt claims could be treated as “deposits" under Section 21(a). DOJ ignored the fact that Merrill Lynch provided its customers

${ }^{60}$ Id.; see United States v. Jenkins, 943 F.2d at 173-74; In re Thaxton Group, Inc., Securities Litigation, supra note 55 , at $* 1-* 3, * 9-* 14$. 
with the functional equivalent of deposits by (i) maintaining a stable value - a fixed NAV of $\$ 1$

per share - for the money market funds held in customer accounts, (iii) allowing customers to withdraw their funds with the same stable value by making redemption requests or writing checks, and (iii) enabling customers to transfer their funds with the same stable value to third parties by writing checks. ${ }^{61}$

DOJ's 1979 opinion should not be considered a binding precedent. That opinion's formalistic reasoning is not consistent with either Section 21(a)'s functional description of “deposits" or the statute's purpose to "prohibit[] . . . unregulated private banking so far as practicable." The 1979 opinion's reasoning also is not compatible with the functional, pragmatic approach of at least two courts that interpreted Section 21(a) more recently. ${ }^{62}$ DOJ should undertake a fresh review of Section 21(a) and should determine that the statute's functional description of "deposits" includes funds that are received from and held on behalf of customers with the understanding that customers may withdraw or transfer those funds by using "checks" (or functionally equivalent methods of payment) or by making "requests" for repayment.

Based on the foregoing determination, DOJ should issue a rule declaring that issuers and distributors of stablecoins providing a fixed 1:1 parity with the U.S. dollar or another widelyused fiat currency are "engag[ing] . . in the business of receiving deposits" if they receive funds from customers, hold stablecoins on behalf of customers, and allow customers to redeem,

\footnotetext{
${ }^{61}$ Gorton \& Zhang, supra note 7, at 10-12, 33-35; Howell E. Jackson \& Morgan Ricks, "Locating Stablecoins Within the Regulatory Perimeter," Harvard Law School Forum on Corporate Governance (Aug. 5, 2021), https://corpgov.law.harvard.edu/2021/08/05/locating-stablecoins-within-the-regulatory-perimeter/.; Wilmarth, Taming the Megabanks, supra note 25, at 153-54.

62 See United States v. Jenkins, 943 F.2d at 173-74; In re Thaxton Group, Inc., Securities Litigation, supra note 55, at *1-*3, *9-*14; Jackson \& Ricks, supra note 61 ("The legislative history of section 21(a)(2) confirms that the provision was intended to "prohibit[]. . . unregulated private banking so far as practicable."') (quoting Senate Report No. 1007, 74th Cong., 1st Sess. 15 (1935)). See also Gorton \& Zhang, supra note 7, at 10-12, 33-35; Wilmarth, "Pandemic Crisis," supra note 15, at 8, 20-21 n.45; Wilmarth, Taming the Megabanks, supra note 25, at 137-39, $153-54$.
} 
withdraw, or transfer their stablecoins. Pursuant to Section 21(a)(1), DOJ's rule should prohibit issuers and distributors of stablecoins that are determined to be "securities" from also receiving, holding, and allowing redemptions, withdrawals, or transfers of customers' stablecoins.

For stablecoins that are determined not to be "securities," DOJ's rule should describe the criteria that issuers and distributors of those stablecoins must satisfy under Section 21(a)(2). DOJ's rule should make clear that issuers and distributors of stablecoins may not receive, hold, and allow redemptions, withdrawals, or transfers of customers' stablecoins unless those issuers and distributors are either (A) chartered, examined, and regulated as deposit-taking banks, or (B) legally authorized to engage in the business of receiving deposits while also being examined and regulated in their conduct of that business, or (C) complying with the same examination and reporting requirements as are applied to deposit-taking banks by the "banking authority" of the relevant state, District, or U.S. territory. ${ }^{63}$

Some might argue that DOJ should not bring enforcement proceedings against issuers and distributors of stablecoins under Section 21(a) unless DOJ takes similar measures against other nonbanks providing financial services that are functionally equivalent to deposits. Such nonbanks would include money market funds as well as payment service providers such as PayPal and its subsidiary Venmo, which hold customer balances and allow customers to withdraw or transfer those balances to others. I would personally welcome a decision by DOJ to take an across-the-board approach, and I believe DOJ would have authority under Section 21(a)

\footnotetext{
6312 U.S.C. $§ 378(a)$; see Gorton \& Zhang, supra note 7, at 33-35; Jackson \& Ricks, supra note 61; Wilmarth, "Pandemic Crisis," supra note 15, at 8-10, 20-21 n.45 (contending that an issuer or distributor of stablecoins would not comply with Section 21(a)(2) if it merely obtained a state money transmitter license and complied with FinCEN's AML requirements, as those limited forms of regulation would not be "equivalent to bank regulation and supervision in any meaningful sense"); see also MoneyGram Int'l Inc. v. Commissioner, 999 F.3d 269 (5th Cir. 2021) (holding that a state-licensed money transmitter was not a "bank" because it did not accept "deposits"); Awrey, supra note 7, at 7-8, 40-56 (describing the "alarming . . permissiveness" of state laws regulating money transmitters, a situation that "undermines the credibility of [money transmitters'] monetary commitments").
} 
to institute enforcement proceedings against money market funds, PayPal, and Venmo. ${ }^{64}$

However, DOJ is not required to act against all violators of Section 21(a) at the same time. DOJ could reasonably decide to focus on stablecoins as a particularly dangerous form of unauthorized deposit-taking that should be stopped before DOJ determines how to deal with similar problems created by money market funds, PayPal, and Venmo. ${ }^{65}$

\section{c. Congress should pass legislation mandating that all issuers and distributors of stablecoins must be FDIC-insured banks.}

\section{i. Requiring all issuers and distributors of stablecoins to be}

FDIC-insured banks would remove uncertainties and gaps in

\section{Section 21(a) of the Glass-Steagall Act.}

I strongly support PWG's recommendation that Congress should "promptly" pass legislation requiring all issuers of stablecoins to be FDIC-insured banks. ${ }^{66}$ Such legislation is urgently needed to overcome uncertainties and gaps that currently exist in Section 21(a) of the Glass-Steagall Act. As explained in the preceding section, an issuer or distributor of stablecoins could offer services that are functionally equivalent to deposits and avoid violating Section 21(a) if it could show that (1) its stablecoins are not "securities," and (2) it is either (A) chartered, regulated, and examined as a deposit-taking bank, or (B) legally authorized to engage in the business of receiving deposits and subject to examination and regulation in conducting that

\footnotetext{
${ }^{64}$ Wilmarth, "Pandemic Crisis," supra note 15, at 7-10; see also Gorton \& Zhang, supra note 7, at 33-35; Jackson \& Ricks, supra note 61.

${ }^{65}$ See United States v. Central Adjustment Bureau, Inc., 823 F.2d 880 (5th Cir. 1987) (holding that "Congress can attack particular evils on a step by step basis," and Congress had a rational basis for passing the Fair Debt Collection Act, which prohibited abusive practices by independent debt collectors without addressing similar abuses by other types of debt collectors); see also Minnesota v. Clover Leaf Creamery Co., 449 U.S. 456, $461-70$ (1981) (quote at 466) (holding that state legislatures "need not "strike at all evils at the same time or in the same way," and the Minnesota legislature had a rational basis for banning nonreturnable plastic milk jugs to protect the environment without also prohibiting nonreturnable paperboard milk containers) (quoting Semler v. Oregon State Bd. of Dental Examiners, 294 U.S. 608, 610 (1935)).

${ }^{66}$ PWG Report, supra note 1, at 2, 16.
} 
business, or (C) subject to the same examination and reporting requirements as are applied to chartered, deposit-taking banks by the "banking authority" of the relevant state, District, or U.S. territory.

The terms of Section 21(a)(2) contain potential ambiguities that would need to be resolved by DOJ and the courts. For example, what precise levels of examination and regulation are needed to satisfy paragraph (B), and what exact types of examinations and reports are required to comply with paragraph (C)? States that wanted to attract entry by stablecoin issuers and distributors could enact laws designed to exploit those ambiguities by granting the most lenient possible treatment to stablecoin providers. ${ }^{67}$

Even more troubling, an issuer or distributor of stablecoins would qualify under paragraph (A) of Section 21(a)(2) if it could obtain a charter for an uninsured depository institution from a federal or state banking authority. Until recently, a deposit-taking bank could not receive either a federal or state charter unless it also obtained deposit insurance from the FDIC and became subject to the full panoply of laws governing FDIC-insured banks. Federal law currently requires all national banks that accept deposits to obtain FDIC insurance. Prior to 2019, every state required state-chartered banks to obtain FDIC insurance as a precondition for accepting deposits. ${ }^{68}$

A number of the state laws mandating FDIC insurance for state-chartered banks were enacted in response to widespread failures of non-federally-insured depository institutions during the 1980s and early 1990s. During that period, state-sponsored, privately-funded insurance

\footnotetext{
${ }^{67}$ See Jackson \& Ricks, supra note 61.

${ }^{68}$ See Barr, Jackson \& Tahyar, supra note 42, at 173-74 (As of 2018, "Federal law requires that all national banks be FDIC insured, and all state laws require that a state-chartered commercial bank obtain FDIC insurance."); 12 U.S.C. $\S 222$ ("Every national bank in any State shall . . become a member bank of the Federal Reserve System . . . and shall thereupon be an insured bank under the Federal Deposit Insurance Act"); Wilmarth, "Banking Privileges," supra note 26 , at 2-7.
} 
systems for state-chartered depository institutions collapsed in several states, with the worst disasters occurring in Ohio, Maryland, and Rhone Island. The injuries suffered by depositors and local economies were particularly severe in Rhode Island, where non-federally-insured depositors lost access to at least some of their deposits for nearly three years. ${ }^{69}$

Despite the dismal record of non-federally-insured depository institutions, Wyoming and Nebraska have passed laws during the past two years that authorize charters for uninsured “special purpose depository institutions" (SPDIs) in Wyoming and uninsured "digital asset depositories" (DADs) in Nebraska. Wyoming and Nebraska allow SPDIs and DADs to accept deposits (including deposits of digital assets) and engage in other cryptocurrency-related activities without obtaining FDIC insurance. Wyoming has already approved four SPDI charters, including one awarded to Kraken, a major cryptocurrency venture. ${ }^{70}$

In December 2020, Figure Technologies (Figure) applied to the OCC to obtain a charter for a national bank that would accept only "jumbo" deposits larger than $\$ 250,000$ (the current limit for federal deposit insurance). Figure asserted that it could avoid any obligation to obtain FDIC insurance by accepting only jumbo deposits. The OCC has not acted on Figure's application, and state regulators have challenged the OCC's legal authority to approve any

\footnotetext{
${ }^{69}$ Quian Chen et al., "The Macroeconomic Fallout of Shutting Down the Banking System," 105 Economic Review No. 2, at 31 (Fed. Res. Bank of K.C., 2020), https://www.kansascityfed.org/documents/8185/v105n2sharma.pdf; Walker F. Todd, "Lessons from the Collapse of Three State-Chartered Private Insurance Funds," Economic Commentary (Fed. Res. Bank of Cleve., May 1, 1994), https://www.clevelandfed.org/en/newsroom-andevents/publications/economic-commentary/economic-commentary-archives/1994-economic-commentaries/ec19940501-lessons-from-the-collapse-of-three-state-chartered-private-deposit-insurance-funds.aspx; see also Christine Bradley \& Valentine V. Craig, "Privatizing Deposit Insurance: Results of the 2006 FDIC Study," 1 FDIC Quarterly No. 2, at 23, 28-30 (2007) (discussing the collapses of numerous state-sponsored private insurance systems for depository institutions between the 1830s and the 1990s), https://www.fdic.gov/analysis/quarterlybanking-profile/fdic-quarterly/2007-vol1-2/privatizing-deposit-insurance.pdf.

${ }^{70}$ See Gorton \& Zhang, supra note 7, at 20; Wyoming Division of Banking, "Special Purpose Depository Institutions," https://wyomingbankingdivision.wyo.gov/banks-and-trust-companies/special-purpose-depositoryinstitutions; "Nebraska Financial Innovation Act," Neb. Rev. Stat. Ch. 8, Art. 30, available at https://ndbf.nebraska.gov/about/legal/financial-innovation-act.
} 
charters for uninsured, deposit-taking national banks. ${ }^{71}$ Nevertheless, Figure and other cryptocurrency companies recently met with the Fed, FDIC, and OCC to discuss "how to issue a stablecoin that satisfies" regulators. ${ }^{72}$

Wyoming's and Nebraska's new laws and Figure's charter application are designed to produce charters for uninsured deposit-taking banks that can issue and distribute stablecoins and engage in other cryptocurrency activities. As indicated above, uninsured banks - if lawfully chartered and legally authorized to receive deposits - could issue and distribute stablecoins that are not "securities" without violating Section 21(a)(2)(A) of the Glass-Steagall Act. They also would not be required to comply with the Federal Deposit Insurance Act (FDI Act) or the BHC Act. As explained in the next section, the FDI Act and the BHC Act establish crucial public interest safeguards that govern FDIC-insured banks and their parent companies. ${ }^{73}$ Congress should make certain that those safeguards apply to all institutions that engage in the business of receiving either bank deposits or "shadow deposits." Ongoing efforts by cryptocurrency ventures to obtain charters for uninsured, deposit-taking banks have cast a very bright light on a dangerous gap in existing laws. Congress must quickly pass legislation that will close that gap by requiring all issuers and distributors of stablecoins to be FDIC-insured banks.

\section{ii. Congress should require all issuers and distributors of} stablecoins to be FDIC-insured banks, thereby bringing those entities within the scope of the FDI Act and the BHC Act.

\footnotetext{
${ }^{71}$ Lydia Beyoud, "Fintech Charter Suit on Hold as Bank Regulator Reviews Policies," Bloomberg Law (June 17, 2021); Lydia Beyoud, "Fintech Lender's Bank Bid Says 'No Thanks' on Deposit Insurance," Bloomberg Law (Dec. $3,2020)$.

72 Jesse Hamilton, "Stablecoin Advocates Make Their Case to U.S. Banking Regulators," Bloomberg Law (Nov. 22, 2021).

${ }^{73}$ See Gorton \& Zhang, supra note 7, at 3-6, 17-21, 33-35, 38-39; Wilmarth, "Banking Privileges," supra note 26, at $1,6-11$.
} 
PWG's report urged Congress to act "promptly" in passing legislation that would require all issuers of stablecoins to be FDIC-insured banks. ${ }^{74}$ The same requirement should apply to entities, such as Facebook's Novi, that distribute stablecoins issued by other companies. Firms that distribute stablecoins to the public should not be allowed to avoid compliance with the FDI Act and the BHC Act simply because their deposit-taking and payment networks employ stablecoins issued by other companies.

Legislation requiring all issuers and distributors of stablecoins to be FDIC-insured banks would guarantee that those firms must comply with crucial public interest safeguards in the FDI Act. Those safeguards include: (a) deposit insurance coverage, payment of risk-based deposit insurance premiums, and reporting and examination requirements under 12 U.S.C. $\S \S 1817$, $1820 \& 1821$; (b) supervisory and enforcement powers granted to federal bank regulators under 12 U.S.C. § 1818; (c) procedures for resolving failed and failing banks under 12 U.S.C. §§ $1821(c), 1822 \& 1823$; (d) risk-based capital requirements and other safety and soundness standards under 12 U.S.C. $§ § 1831$ p-1 \& 3901-07; (e) prompt corrective action remedies under 12 U.S.C. $\S 1831$; ; (f) safety and soundness requirements and protections for competition that govern proposed changes in control of banks and bank mergers under 12 U.S.C. $\S \S 1817(\mathrm{j}) \&$ 1828(c); (f) prohibitions on abusive tying practices under 12 U.S.C. $§ \S 1971-77$; (f) "source of strength" obligations and capital requirements for parent companies of FDIC-insured banks under 12 U.S.C. $\S \S 18310-1 \& 5371$ (b); (g) community reinvestment duties under 12 U.S.C. §§ 3901-08; and (h) expedited funds availability requirements under 12 U.S.C. $\S \S 4001-10$.

Mandating status as FDIC-insured banks for all issuers and distributors of stablecoins would also make certain that those entities are treated as "banks" for purposes of the BHC Act. ${ }^{75}$

\footnotetext{
${ }^{74}$ PWG Stablecoin Report, supra note 1, at 2, 16.

7512 U.S.C. $\S 1841$ (c)(1)(A) (defining "bank" for purposes of the BHC Act to include all FDIC-insured banks).
} 
The BHC Act requires all companies that own or control FDIC-insured banks to comply with additional public interest safeguards, including (a) safety and soundness standards and protections for competition governing proposed acquisitions of banks under 12 U.S.C. § 1842; (b) limitations on permissible nonbanking activities under 12 U.S.C. § 1843; (c) the Fed's authority to conduct examinations, require reports, bring enforcement actions, adopt supervisory rules, and impose risk-based capital requirements under 12 U.S.C. $\S \S 1818,1844,1847$, \& 5371(b); and (d) privacy protections that (i) prohibit financial holding companies from disclosing nonpublic customer information to unaffiliated third parties against their customers' wishes, and (ii) bar third parties from using false or deceptive practices to obtain such information (15 U.S.C. $\S \S 6801-09,6821-27)$.

One of the BHC Act's most important provisions is 12 U.S.C. § 1843, which prohibits companies that own or control banks from engaging in commercial activities or owning commercial enterprises. Section 1843 prevents the formation of banking-and-commercial conglomerates that would pose grave dangers to our society, financial system, and economy, including (1) hazardous concentrations of economic and financial power and political influence, (2) toxic conflicts of interest that would destroy the ability of banks to act objectively in providing credit and other services, and (3) risks of systemic contagion between financial and commercial sectors that could inflict enormous losses on the federal "safety net" for banks (including the FDIC's deposit insurance fund, the Fed's discount window, and the Fed's guarantee for interbank payments made on Fedwire, as well as the federal government's explicit and implicit protections for "too big to fail" banking organizations). Requiring all issuers and distributors of stablecoins to be FDIC-insured banks would prevent stablecoin ventures from 
being owned or controlled by commercial enterprises, including Big Tech firms like Apple, Amazon, Facebook, Google, and Microsoft. ${ }^{76}$

Stopping Big Tech firms from acquiring ownership or control of issuers and distributors of stablecoins should be a top priority for financial regulators and Congress. Big Tech firms already enjoy significant advantages over traditional providers of financial services in areas such as automation, artificial intelligence, data management, and mobile payments. The rapid expansion of Ant Financial (Alipay) and Tencent (WePay) in China - prior to the crackdown on both companies by Chinese authorities in 2020 - indicates that Big Tech firms could potentially dominate major segments of our financial industry if they were allowed to offer deposit and payment services. The entry of Big Tech firms into the banking business would create a wide range of potential threats, including unfair competition, market dominance, predatory lending, abusive sharing of customer data and other violations of customer privacy rights, as well as much greater risks of systemic contagion across financial and nonfinancial sectors of our economy during financial crises and severe economic downturns. ${ }^{77}$

\footnotetext{
${ }^{76}$ Wilmarth, "Banking Privileges," supra note 26, at 6-11; Arthur E. Wilmarth, Jr., "The FDIC Should Not Allow Commercial Firms to Acquire Industrial Banks," 39 Banking \& Financial Services Policy Report No. 5 (May 2020), at 1, 2-10 [hereinafter Wilmarth, "Industrial Banks"], available at https://ssrn.com/abstract=3613022; Arthur E. Wilmarth, Jr., "Wirecard and Greensill Scandals Confirm Dangers of Mixing Banking and Commerce," 40 Banking \& Financial Services Policy Report No. 5 (May 2021), at 1, 11-12 [hereinafter Wilmarth, "Wirecard and Greensill"], available at https://ssrn.com/abstract=3849567.

${ }^{77}$ See Raúl Carrillo, Testimony before the Subcomm. on Consumer Protection and Financial Institutions of the House Comm. on Financial Services 7-9 (April 15, 2021) [hereinafter Carrillo Testimony], https://docs.house.gov/meetings/BA/BA15/20210415/111447/HHRG-117-BA15-Wstate-CarrilloR-20210415.pdf; Kathryn Petralia, Thomas Philippon, Tara Rice \& Nicholas Véron, Banking Disrupted? Financial Intermediation in an Era of Transformational Technology 25-38, 44-82 (Geneva Reports on the World Economy 22, 2019), https://www.cimb.ch/uploads/1/1/5/4/115414161/banking_disrupted_geneva22-1.pdf; Investigation of Competition in Digital Markets: Majority Staff Report and Recommendations (Subcomm. on Antitrust, Commercial and Administrative Law of the House Comm. on the Judiciary, 2020) [hereinafter 2020 House Staff Report on Competition in Digital Markets], https://judiciary.house.gov/uploadedfiles/competition_in_digital_markets.pdf; Wilmarth, "Banking Privileges," supra note 26, at 6-11; Wilmarth, "Industrial Banks," supra note 76, at 4-10; Wilmarth, "Wirecard and Greensill," supra note 76, at 11-13.
} 
Facebook's plan to offer deposit and payment services through Novi poses unacceptable threats to consumer privacy and welfare. Facebook has repeatedly abused its customers' privacy rights and has reportedly marketed products that it knew were harmful to its customers. In 2012, Facebook entered into a consent decree with the Federal Trade Commission (FTC) to settle charges that it deceived customers and violated its promises to allow customers to control the privacy of information they posted on Facebook. In 2019, Facebook paid a $\$ 5$ billion fine to resolve the FTC's charges that Facebook violated the privacy commitments included in the 2012 consent decree. ${ }^{78}$ The FTC recently launched a new investigation of Facebook after a whistleblower informed Congress that Facebook knew from its internal research that some of its products caused mental health problems in minors as well as other harms to customers. ${ }^{79}$

Facebook has long sought to enter the financial services industry to extend its dominance over social networks and expand its access to customer information. In 2012, Facebook founder and CEO Mark Zuckerberg said that the launch of a successful payment service would give Facebook "a pretty awesome combo and a good reason for people to use [Facebook's] platform," as well as making it "more acceptable for us to charge them quite a bit more for using [our] platform." ${ }^{80}$ Offering deposit and payment services would greatly increase Facebook's ability to access, leverage, and monetize its customers' private information. As Open Markets Institute recently pointed out,

\footnotetext{
78 “FTC Imposes \$5 Billion Penalty and Sweeping New Privacy Restrictions on Facebook," (Fed. Trade Comm'n, July 24, 2019), https://www.ftc.gov/news-events/press-releases/2019/07/ftc-imposes-5-billion-penalty-sweepingnew-privacy-restrictions.

${ }_{79}$ John D. McKinnon \& Brent Kendall, "Federal Trade Commission Scrutinizing Facebook Disclosures," Wall Street Journal (Oct. 27, 2021), https://www.wsj.com/articles/facebook-ftc-privacy-kids-11635289993; John D. McKinnon \& Ryan Tracy, "Facebook Whistleblower's Testimony Builds Momentum for Tougher Tech Laws," Wall Street Journal (Oct. 5, 2021), https://www.wsj.com/articles/facebook-whistleblower-frances-haugen-set-toappear-before-senate-panel-11633426201.

${ }^{80}$ Open Markets Facebook Letter, supra note 22, at 12 (quoting Zuckerberg's statement).
} 
Facebook occupies a dominant role in American life and indeed the lives of people around the world, with over 1 billion users for four of its services, including Facebook, Instagram, Messenger, and WhatsApp. Facebook is also a giant in the advertising space, with their 2020 advertising revenue close to $\$ 84.2$ billion dollars — nearly $\$ 1.6$ billion each week. ${ }^{81}$

A 2020 House subcommittee staff study found that "Facebook has monopoly power in the market for social networking" and has exploited that market power by becoming a "gatekeeper" with "outsized power to control the fates of other companies." generates most of its revenues by selling digital advertising. Facebook's access to the private information of hundreds of millions of customers enables it to command much higher prices for its sales of advertising, compared with its competitors. ${ }^{83}$ The House staff study concluded that Facebook's dominance of the social networking market - like Google's dominance of the Internet search market - allows Facebook to "abuse consumers' privacy without losing customers. ${ }^{" 84}$ As one expert advised the House subcommittee:

Facebook and Google have built comprehensive dossiers on almost everyone, and they can sell incredibly targeted advertisement on that basis.... But doing so represents an inherent violation of the receiver's privacy. Every ad targeted using personal information gathered without explicit, informed consent is at some level

\footnotetext{
${ }^{81} I d$.

822020 House Staff Report on Competition in Digital Markets, supra note 77, at 12-14, 39-40; see also id. at 132-73 (providing a detailed analysis of Facebook's exploitation of its market power, including its acquisition of numerous competitors).

${ }^{83} \mathrm{Id}$. at $170-72$.

${ }^{84} \mathrm{Id}$. at $18,51-53$.
} 
a violation of privacy. And Facebook and Google are profiting immensely by selling these violations to advertisers. ${ }^{85}$

Novi's deposit and payment services could enable Facebook to collect and monetize a vast array of data about its customers' financial assets and transactions. The treasure trove of nonpublic customer information that Big Tech firms could capture by offering deposit and payment services is indicated by the huge data set compiled by JPMorgan Chase Institute (JPMCI). JPMCI has collected and analyzed a massive pool of information, drawn from the records of JPMorgan Chase (JPMC), the largest U.S. bank, containing the "saving, spending, and borrowing habits of the bank's customers." The Fed "has used the Institute's research when weighing interest-rate decisions," thereby confirming the enormous value of JPMC's comprehensive information about its customers' financial dealings. ${ }^{86}$ Allowing Facebook and other Big Tech firms to build similar data sets by offering deposit and payment services would increase exponentially their ability to monetize customer information and degrade customer privacy by secretly transferring that information to third-party sellers of goods and services.

Requiring all issuers and distributors of stablecoins to be FDIC-insured banks would guarantee that all companies that own or control those entities must comply with the privacy protections governing financial holding companies (15 U.S.C. $\S \S 6801-09,6821-27)$. That requirement would also prevent Facebook and other Big Tech firms from offering deposit and payment services built around stablecoins. The PWG Report correctly determined that "the combination of a stablecoin issuer or [digital] wallet provider and a commercial firm could lead

\footnotetext{
${ }^{85} \mathrm{Id}$. at 54-55 (quoting testimony of David Heinemeier Hansson, co-founder and chief technology officer of Basecamp).

${ }^{86}$ David Benoit, "How JPMorgan Is Helping Washington Make Sense of the Pandemic Recovery," Wall Street Journal (Nov. 9, 2021), https://www.wsj.com/articles/how-jpmorgan-is-helping-washington-make-sense-of-thepandemic-economy-11636462980.
} 
to an excessive concentration of economic power," which could "restrict access" to credit and other financial services and have "detrimental effects on competition.",87

Our nation stands at a crossroads. We can maintain the BHC Act's longstanding policy of separating banking and commerce, thereby preserving a financial sector, a national economy, and a society that are not compromised by toxic conflicts of interest, exploited by unfair competitive advantages, or dominated by the overwhelming economic power and political influence of giant banking-and-commercial conglomerates. Or we can allow Facebook and other Big Tech firms to enter the banking business and leverage their stablecoin ventures to create massive "shadow banking" empires, thereby subverting the BHC Act's separation of banking and commerce. In that event, Big Tech firms might well gain dominance over our banking industry - either by building their own financial kingdoms or by combining with our largest banks - thereby creating the very evils that the BHC Act was designed to prevent. ${ }^{88}$

\section{iii. The FDIC should not approve pass-through deposit insurance coverage for stablecoins.}

The FDIC is reportedly considering the possibility of allowing FDIC-insured banks to hold reserves deposited by stablecoin issuers and provide "pass-through" deposit insurance coverage to customers of those issuers. ${ }^{89}$ The FDIC currently grants pass-through deposit insurance coverage to holders of stored-value cards if the issuers of those cards satisfy the following conditions: (i) each issuer must establish a custodial deposit account at an FDICinsured bank to hold the funds owned by card holders, (ii) the issuer must allow card holders to

\footnotetext{
${ }^{87}$ PWG Stablecoin Report, supra note 1, at 14.

${ }^{88}$ Carrillo Testimony, supra note 77, at 7-9; Wilmarth, "Banking Privileges," supra note 26, at 6-11; Wilmarth, "Industrial Banks," supra note 76, at 4-12; Wilmarth "Wirecard and Greensill," supra note 76, at 11-14.

${ }^{89}$ Nate DiCamillo, "US FDIC Said to Be Studying Deposit Insurance for Stablecoins," CoinDesk (Oct. 6, 2021), https://www.coindesk.com/policy/2021/10/06/us-fdic-said-to-be-studying-deposit-insurance-for-stablecoins/.
} 
access their funds at the bank through withdrawals or transfers to third parties, (iii) the bank's records must confirm that the issuer has established a custodial deposit account holding funds owned by card holders, (iv) either the bank's records or the issuer's records must show, on an accurate and current basis, the identity of each card holder and the amount of funds owned by that holder, and (v) the issuer must inform card holders that their funds are held in a custodial account at the bank. ${ }^{90}$

Approving pass-through deposit insurance for stablecoins would involve a number of operational difficulties. One of the most significant challenges would be the requirement that either the custodial bank or the stablecoin issuer must maintain current and accurate records showing the identity of each holder of stablecoins and the amount of stablecoins owned by that holder. As the PWG's report pointed out,

The majority of the stablecoin market currently operates on public blockchains where transactions may be pseudonymous, meaning the identity of the sender or the receiver of a transaction is unknown, but other transactional information is available (e.g., the amount, the time, the value, etc.)." ${ }^{\prime 1}$

Indeed, the relative anonymity of transactions conducted with stablecoins - compared with traditional payment methods other than cash - is a major reason for the popularity of stablecoins. ${ }^{92}$

It is difficult to envision how stablecoin issuers and custodial banks could maintain accurate and current records showing the identities of holders of stablecoins and the amounts of

\footnotetext{
${ }^{90}$ FDIC, New General Counsel Opinion No. 8 (Oct. 31, 2008), available at 73 Fed. Reg. 67155-57 (Nov. 13, 2008 ).

${ }^{91}$ PWG Stablecoin Report, supra note 1, at 19 n.39; see also DiCamillo, supra note 84 (explaining that stablecoins are transferred on "public blockchain networks . . . and theoretically anyone with a crypto wallet that hasn't been blacklisted can receive stablecoins from, and send them to, other wallets.").

${ }^{92}$ See supra notes 11-12 and accompanying text.
} 
coins they own without changing the fundamental nature of stablecoin transactions that are conducted on distributed ledgers (particularly in DeFi transactions). A financial journalist recently described the following problems that stablecoin issuers would confront if "financial regulators declare that all stablecoin owners must be verified":

Building infrastructure to collect and verify the identity of all users [of stablecoins], and not just the few who redeem or deposit, is expensive. To recoup their costs, issuers . . may consider introducing fees. All of this could render stablecoins less accessible for people who only want to use them for casual remittances.

... In DeFI, stablecoins are often deposited into accounts controlled by bits of autonomous code, or smart contracts, which don't have any underlying owner. It's not evident how a stablecoin issuer can conduct KYC [compliance] on a smart contract. $^{93}$

Thus, it would be extremely difficult, if not impossible, for a stablecoin issuer or a custodial bank to maintain an accurate and current record of the identities of stablecoin holders or the amounts of coins they currently own in order to qualify for pass-through deposit insurance coverage from the FDIC.

Moreover, granting pass-through deposit insurance coverage to holders of stablecoins would not remove the systemic perils created by the issuers and distributors of those coins. Passthrough coverage would allow issuers and distributors of stablecoins and their customers to benefit from access to the FDIC's deposit insurance fund. Issuers, distributors, and customers would also benefit indirectly from the custodial bank's access to the Fed's discount window

\footnotetext{
${ }^{93}$ Koning, supra note 11.
} 
advances and payments system guarantees, as well as other components of the federal safety net for banks. In contrast, pass-through deposit insurance coverage would not require issuers and distributors of stablecoins to comply with the FDI Act's provisions that protect customers, communities, businesses, and the stability of the banking system. In addition, pass-through coverage would allow companies that own or control issuers and distributors of stablecoins to avoid complying with the BHC Act's safeguards, including the Fed's regime of consolidated regulation and supervision, the privacy rules governing financial holding companies, and the separation of banking and commerce.

In sum, pass-through deposit insurance coverage would enable Facebook and other Big Tech firms to offer deposit and payment services and receive extensive benefits from the federal safety net for FDIC-insured banks without complying with the public interest mandates governing those banks and their parent companies. Pass-through coverage would effectively create a "back door" that allows Big Tech firms to compete directly with traditional banks, undermine the BHC Act's separation of banking and commerce, and circumvent other important public interest safeguards.

Pass-through deposit insurance coverage for stablecoins would produce many of the harmful effects of "rent-a-bank" arrangements, which the OCC approved when it adopted its socalled "true lender" rule in October 2020. The OCC's rule declared that a national bank would be treated as the "true lender" for a loan as long as the bank funded the loan at closing or was named as the lender in the loan agreement, even if the bank transferred its entire interest and entire risk in the loan to a nonbank "partner" the following day. Under the OCC's rule, nonbanks could have reaped the benefits that their national bank partners enjoyed under federal statutes preempting the application of state usury laws and other state consumer protection laws 
to national banks. ${ }^{94}$ In June 2021, Congress passed a joint resolution that repealed the OCC's rule under the Congressional Review Act. ${ }^{95}$ Members of Congress who supported the joint resolution condemned the OCC's "true lender" rule for allowing predatory nonbank lenders "to use superficial and deceptive partnerships with [national] banks to skirt state laws and charge outrageous annual percentage rates" on loans they acquired from their national bank partners. ${ }^{96}$

The FDIC should reject pass-through deposit insurance coverage for stablecoins for the same reasons that Congress repealed the OCC's "true lender" rule. Issuers and distributors of stablecoins should not be allowed to obtain the benefits provided by FDIC insurance and other components of the federal safety net for banks unless those entities become FDIC-insured banks. Issuers and distributors of stablecoins and their parent companies should not be allowed to use "rent-a-bank" arrangements to engage in destructive regulatory arbitrage. Instead, they should be required to comply fully with the essential public interest safeguards contained in the FDI Act and the BHC Act. ${ }^{97}$

\section{Conclusion}

The PWG's report provides a welcome blueprint for top-priority actions by regulatory agencies and Congress. The SEC should use its existing powers to regulate stablecoins as

\footnotetext{
${ }^{94}$ Wilmarth, "Banking Privileges," supra note 26, at 2, 14-17; see also Carrillo Testimony, supra note 77, at 6-7; Adam J. Levitin, "Rent-a-Bank: Bank Partnerships and the Evasion of Usury Laws," 71 Duke Law Journal 329 (2021).

${ }^{95}$ Davis Polk, "Client Update: The OCC's true lender rule has been repealed" (July 1, 2021), https://www.davispolk.com/insights/client-update/occs-true-lender-rule-has-been-repealed.

${ }^{96}$ Senate Comm. on Banking, Housing, and Urban Affairs, "Majority Press Release: President Signs Van Hollen, Brown Legislation to Strike Down Trump-era 'Rent-a-Bank' Rule" (June 30, 2021) (quote), https://www.banking.senate.gov/newsroom/majority/president-signs-van-hollen-brown-legislation-to-strike-downtrump-era-rent-a-bank-rule; see also House Financial Services Comm., "Press Release: Waters Floor Statement on House Passage of Resolution to Eliminate Trump's Predatory 'True Lender' Rule” (June 25, 2021), https://financialservices.house.gov/news/documentsingle.aspx?DocumentID=408055.

${ }^{97}$ See Carrillo Testimony, supra note 77, at 7-9 (supporting the proposed "STABLE Act," introduced in December 2020 by three House members); see also Press Release, "Tlaib, García, and Lynch Introduce Legislation Protecting Consumers Against Cryptocurrency-Related Financial Threats" (Dec. 2, 2020) (describing the proposed STABLE Act), https://tlaib.house.gov/media/press-releases/tlaib-garcia-and-lynch-stableact.
} 
"securities" and protect investors and securities markets. DOJ should designate stablecoins as "deposits" and bring enforcement actions to prevent issuers and distributors of stablecoins from violating Section 21(a) of the Glass-Steagall Act. To overcome uncertainties and gaps in the remedies available to the SEC and DOJ, Congress should pass legislation requiring all issuers and distributors of stablecoins to be FDIC-insured banks. The foregoing measures are urgently needed to counteract the grave dangers that stablecoins pose to our society, financial system, and economy. 